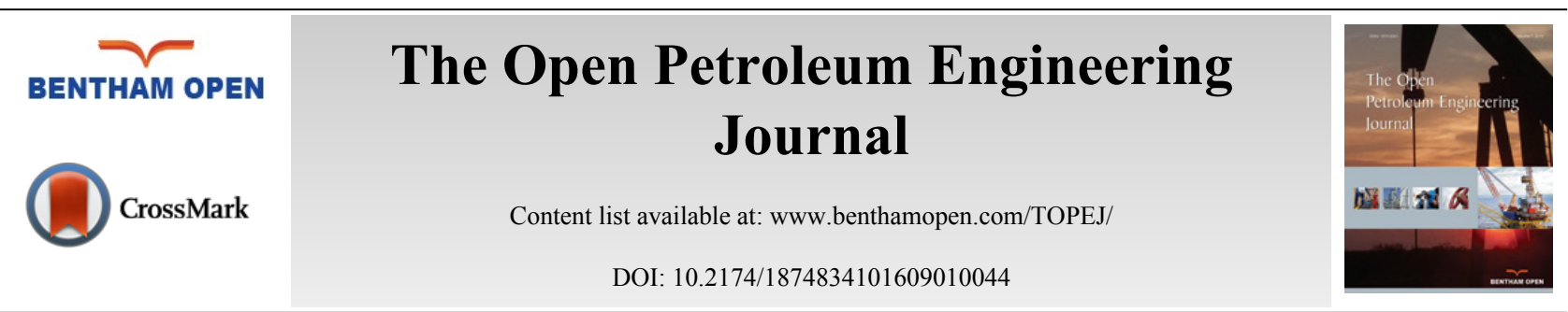

EDITORIAL

\title{
Could Shale be Just a One-hit Wonder? A Comprehensive Overview of the Technology Today for Non-Specialists
}

The following special issue entitled Could shale be just a one-hit wonder?: A comprehensive overview of the technology today for non-specialists tackles an array of topics that have arisen due to the shale gas revolution in the US. Although it may seem as if much has been written on the subject, the truth is the information is contradictory and incomplete. The main purpose of this work is twofold: first, to begin filling in the gaps and second, attempting to set the record straight.

A short preface was provided by Peter Gaffney who comments on the shale situation with the knowledge that only experience brings. Immediately after the first paper, GLOBAL ENERGY DEMAND AND ITS GEOPOLITICAL AND SOCIOECONOMIC IMPLICATIONS: WHICH ROLE WOULD SHALE RESOURCES HAVE? serves as a sort of introduction to the issue inasmuch as it reflects on how the global scene has been affected by shale gas development in the US.

The following four papers dwell on aspects relevant to the technology used for shale gas exploitation. The discussion starts with INDUCED MICROSEISMICITY: SHORT OVERVIEW, STATE OF THE ART AND FEEDBACK ON SOURCE ROCK PRODUCTION. The implications of hydraulic fracturing have been a longtime concern not only for the industry but also for the general population. A lack of proper documentation has ultimately led to the misconception of the technology. The paper that follows A REVIEW OF NUMERICAL SIMULATION STRATEGIES FOR HYDRAULIC FRACTURING, NATURAL FRACTURE REACTIVATION AND INDUCED MICROSEISMICITY PREDICTION provides knowledge on the modeling approaches adopted to understand hydraulic fracturing, natural fracture reactivation and resulting induced microseismicity as the interconnected phenomena involved in shale gas production. The subsequent paper SHALE RESERVOIR-CENTRIC COMPLETIONS discusses how engineers and geoscientists can identify important parameters necessary for optimum well completion design. Closing this section is PRACTICAL CONSIDERATIONS FOR WELL PERFORMANCE ANALYSIS AND FORECASTING IN SHALE PLAYS in which it is argued that production diagnostics are the key to understanding well performance behavior prior to analysis and modeling.

The last paper APPLYING SUSTAINABLE DEVELOPMENT PRINCIPLES AND SUSTAINABLE OPERATING PRACTICES IN SHALE OIL AND GAS PRODUCTION eloquently argues and recommends best practices and the application of sustainable development principles and sustainable operating practices in order to tackle resistance toward shale oil/gas extraction in many parts of the world.

\section{DISCLAIMER}

The views and opinions expressed in the articles in this special issue are those of the author(s) and do not necessarily reflect the views or opinions of the guest editor or the publisher. 
Francesca Verga

Petroleum Engineering Program - DIATI,

Politecnico di Torino, Corso Duca degli Abruzzi, 24,

10129 Torino

Italy

(C) Francesca Verga; Licensee Bentham Open.

This is an open access article licensed under the terms of the Creative Commons Attribution-Non-Commercial 4.0 International Public License (CC BY-NC 4.0) (https://creativecommons.org/licenses/by-nc/4.0/legalcode), which permits unrestricted, non-commercial use, distribution and reproduction in any medium, provided the work is properly cited. 